\title{
Chromian spinel-rich black sands from eastern shoreline of Andaman Island, India: Implication for source characteristics
}

\author{
Koyel Bhatta and Biswajit Ghosh* \\ Department of Geology, University of Calcutta, 35 Ballygunge Circular Road, Kolkata 700 019, India. \\ ${ }^{*}$ Corresponding author. e-mail: bghosh_geol@hotmail.com
}

Black sands rich in chromian spinel commonly occur in pockets along the eastern shoreline of Andaman Island where various types of peridotites and volcanics belonging to the Andaman ophiolite suite are exposed in close vicinity. The chemistry of these detrital chromian spinels has been extensively used here in identifying the source rocks vis-à-vis deciphering the source characteristics. The composition of the chromian spinels (Cr\#: 0.20-0.88, $\mathrm{Mg} \#$ : 0.26-0.77, $\mathrm{Al}_{2} \mathrm{O}_{3}$ : 5.04-48.21 wt.\%, $\mathrm{TiO}_{2}$ : up to 1.39 wt.\% and $\left.\mathrm{Fe}^{2+} / \mathrm{Fe}^{3+}: 1.73-9.12\right)$ varies widely signifying multiple sources, of which mantle peridotites and volcanic rocks are relevant in an ophiolitic terrain. The volcanic chromian spinels are relatively fresh, commonly euhedral, sometimes with compositional variations, and contain inclusions in contrast to the mantle peridotitic chromian spinels which are rounded, extensively fractured, and altered. We used a number of geochemical bivariate plots in order to know the provenance protoliths. The volcanic chromian spinels show geochemical characters of MORB, related to spreading centers (either MOR or back-arc) and also boninites/arc-tholeiites, related to active subduction. On the other hand, the peridotitic spinels indicate partially depleted lherzolite and depleted harzburgite source of the ophiolite suite.

\section{Introduction}

Chromian spinel (hereafter 'spinel') is one of the major heavy minerals among the spinel group found in sediments and sedimentary rocks. It has immense geodynamic implications and is known to be a provenance marker of mafic and ultramafic rocks, especially Alpine-type peridotites (Press 1986; Arai and Okada 1991; Cookenboo et al. 1997; Lee 1999). Due to the high mechanical and chemical resistivity of spinel grains, it usually forms beach placers. The spinel compositions, known to be influenced by the geodynamic environment of formation (Evans and Frost 1975; Dick and Bullen 1984; Sack and Ghiorso 1991; Barnes and Roeder 2001) are sensitive petrogenetic indicators (Dick and Bullen 1984; Barnes 1986; Auge 1987; Arai
1992; Zhou et al. 1996; Melcher et al. 1997; Bedard 1999; Kamenetsky et al. 2001). The mantle spinels either in the form of massive chromitite or as disseminated grains occur both in the arc-peridotites as well as in the abyssal zone peridotites. Their chemical compositions can be correlated with caution (Ghosh et al. 2014a) with their formation in different tectonic settings, specifically island arcs and nascent spreading centers, such as back-arc basins (Zhou and Robinson 1994, 1997).

The Andaman ophiolite preserves a thin crustal section consisting of cumulate rocks and volcanics and a relatively thicker mantle section (peridotite), which contains abundant spinels with diverse chemical compositions (Ghosh et al. 2009, 2013; Ghosh and Bhatta 2014). Natural concentration of black sands as beach placers, with detrital spinels

Keywords. Chromian spinel; detrital sand; ophiolites; Andaman Island; India. 
being a dominant phase occurs at places along the eastern shoreline of the Andaman Island, where the hinterland rock types consist of ophiolite suite of rocks. This exclusive mode of occurrence rules out the possibilities of any other source for these spinels than the ophiolitic rocks. One of the advantages of studying detrital spinels is that we can estimate lithological distributions and variations of the source rocks over a wide area more effectively because streams erode the exposed weathered rocks impartially. That is to say, the detrital spinels can represent in situ spinels in the mantle rocks of the catchment areas to some extent (Kadoshima and Arai 2001). In order to demonstrate a perspective view of petrological characteristics and variations of the Andaman ophiolite, Ghosh et al. (2012) studied the detrital spinels from Andaman Island. Although their work could discriminate the domain representing arc setting from that of rift related setting (either MOR or back-arc), which has a major implication in geodynamic evolution of Andaman ophiolite, well constrained approaches in characterizing these detrital spinels in terms of provenance protolith are not established yet. Spinel morphology differs significantly in the source rocks in ophiolites (Karmalkar et al. 1995, 1997). But this method (on outcrop samples) cannot be applied in dealing with detrital spinels because of abrasive and rounding effects due to transportation and wave action. Here we present the mineral chemistry of the detrital spinels collected from north-, middle- and south-Andaman (figure 1) and discriminate them in terms of their source characteristics purely on geochemical basis. Such studies, in particular for Andaman Island are significant when most of the areas are not accessible owing to dense forest cover, tough physiography, deep weathering profile and inaccessibility to outcrops due to prohibitory orders to protect aboriginals. In addition, serpentinisation and weathering have obliterated the primary mineralogy to a great extent (Ghosh and Morishita 2011), causing difficulty in routine petrographic study, and hence in systematic classification of the outcrop rocks.

\section{Brief geological setting}

Andaman group of islands in the Bay of Bengal, India (figure 1) represent the northern segment of Sunda-Java subduction complex lying seaward of the Andaman Sea (Curray 2005). These islands are located on the outer arc ridge of the Indonesian arc system (Ray et al. 1988; Allen et al. 2007). An oblique subduction $\left(\mathrm{N} 20^{\circ} \mathrm{E}\right)$ of the oceanic part of the Indian plate beneath the Myanmar micro-plate, a part of the much larger Eurasian plate is generally conceived (Paul et al. 2001;
Vigny et al. 2005; Luhr and Haldar 2006). Based on seismic sections, an accretionary prism setting for Andaman Islands consisting of imbricate stack of easterly dipping thrust slices and folds with westerly vergence, linked to westward shifting of the subduction zone has been suggested (Roy 1992; Acharyya 2007).

The rock types of Andaman Island consist of Cretaceous Ophiolite Group at the base, occurring as $\mathrm{N}-\mathrm{S}$ trending dismembered slices at different structural levels, followed by sedimentary rocks of Lower to Middle Eocene Mithakari Group (volcaniclastic), Oligocene to late Eocene Andaman Flysch Group (siliciclastic), and the Mio-Pliocene Archipelago Group (siliciclastic-carbonate) successively (Bandopadhyay 2005) (figure 1). Recently Bandopadhyay (2012) gave a detailed account of the Paleogene sedimentary units and reinterpreted their depositional environments. The ophiolite sequence is represented by tectonised, restitic mantle sequence, progressively overlain by crustal cumulate sequence (layered ultramafic and mafic), plagiogranite-diorite suite (high level intrusives), volcanic rocks and deep sea pelagic sediments. The residual mantle peridotites of ophiolite sequence in Andaman Island are characterized by a broad spectrum of rocks that consists of partially depleted lherzolite and depleted harzburgite with development of olivine-rich dunitic pods. Spinel occurs both as massive chromitite as well as accessory residual anhedral grains showing features of partial melting, uniformly disseminated in the host peridotite (Ghosh et al. 2013). Massive type chromitite includes pods of varying sizes enclosed in serpentinised dunitic envelope within depleted mantle tectonite (Ghosh and Bhatta 2014) and also as millimeterscale chromitite bands in ultramafic cumulates.

\section{Sampling and analytical methods}

The detrital spinel rich black sands (figure 2a and b) were collected along the eastern coast of Andaman Island from the vicinity of Chidiyatapu $\left(11^{\circ} 30^{\prime} 36^{\prime \prime} \mathrm{N} ; \quad 92^{\circ} 42^{\prime} 18^{\prime \prime} \mathrm{E}\right)$ in south-Andaman, Betapur $\left(12^{\circ} 35^{\prime} 12^{\prime \prime} \mathrm{N} ; \quad 92^{\circ} 57^{\prime} 32^{\prime \prime} \mathrm{E}\right)$ in middleAndaman, and south of Kalipur beach $\left(13^{\circ} 12^{\prime} 35^{\prime \prime} \mathrm{N}\right.$; $\left.93^{\circ} 03^{\prime} 11^{\prime \prime} \mathrm{E}\right)$ in north-Andaman. Size variations of the detrital minerals sampled from all the locations are similar and range between 50 and $250 \mu \mathrm{m}$. Noteworthy to mention here is that the effect of wave energies and longshore currents on the eastern coast of Andaman Island that meets the Andaman Sea, a restricted back-arc basin, is minimum in contrast to the western coast which is the open ocean direction (Ghosh et al. 2012).

Electron Probe Micro Analysis (EPMA) was carried out at the EPMA Laboratory of the Geological 


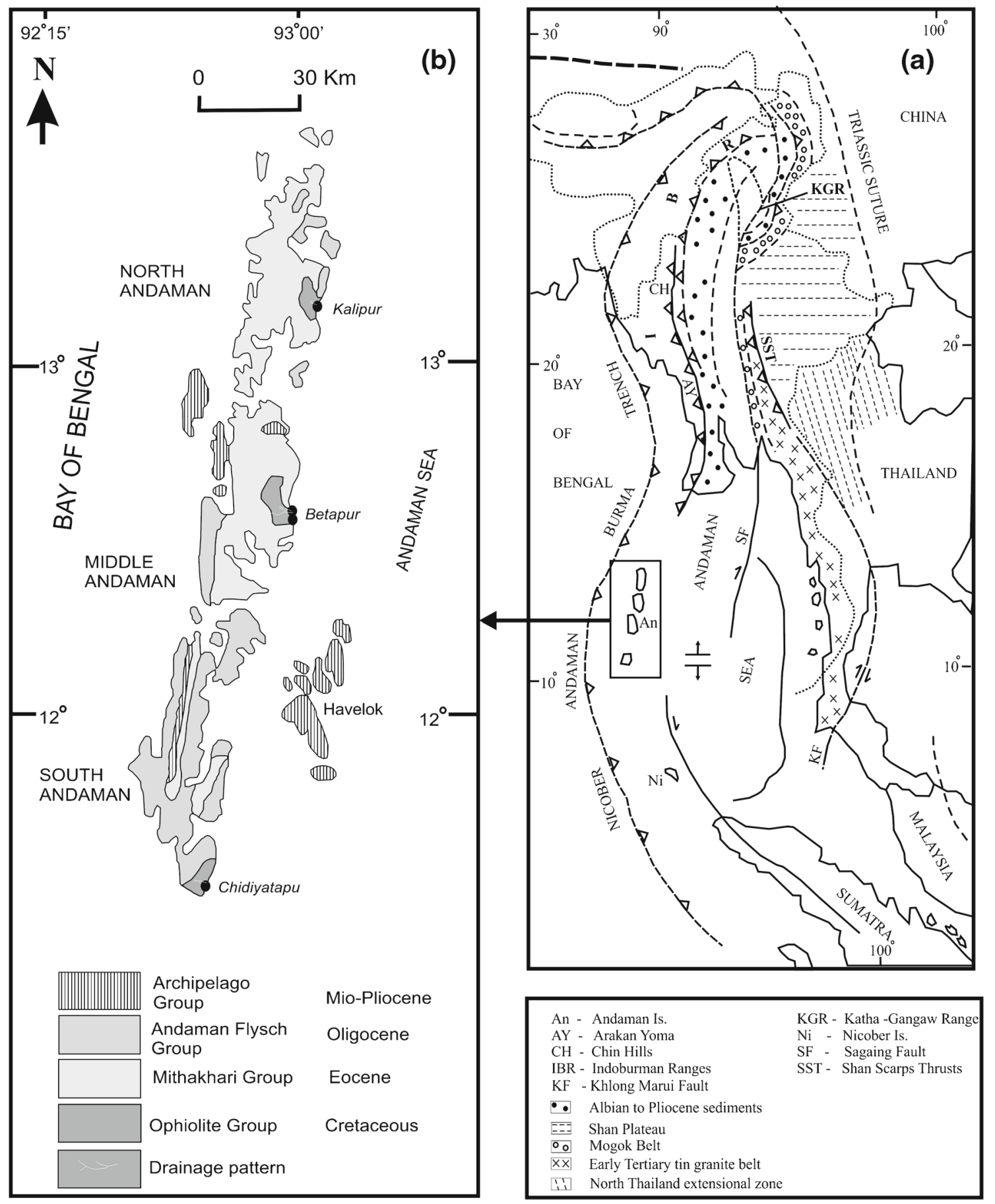

Figure 1. (a) Regional tectonic framework of southeast Asia (redrawn after Mitchell 1985) and (b) the geological map of Andaman Island (modified from Bandopadhyay 2005) showing the distribution of the Ophiolite Group along with other lithostratigraphic units. The sample locations have been marked by filled circles.

Survey of India (GSI), Kolkata on polished sections of mounted grains with a CAMECA SX100 Electron Probe Micro Analyzer at $15 \mathrm{kV}, 12 \mathrm{nA}$ using $1 \mu \mathrm{m}$ beam diameter. The details of sample preparation are described elsewhere (Ghosh et al. 2012). Instrument calibration was performed using mineral standards supplied by BRGM, France and results were corrected with a PAP matrix correction program. The standards were analyzed at regular intervals to check the precision of analysis.

\section{Grain morphology and mineral chemistry}

There is a variety of grain morphology and internal textures exhibited by the detrital spinel grains (figure 3). The documentation for each of the 

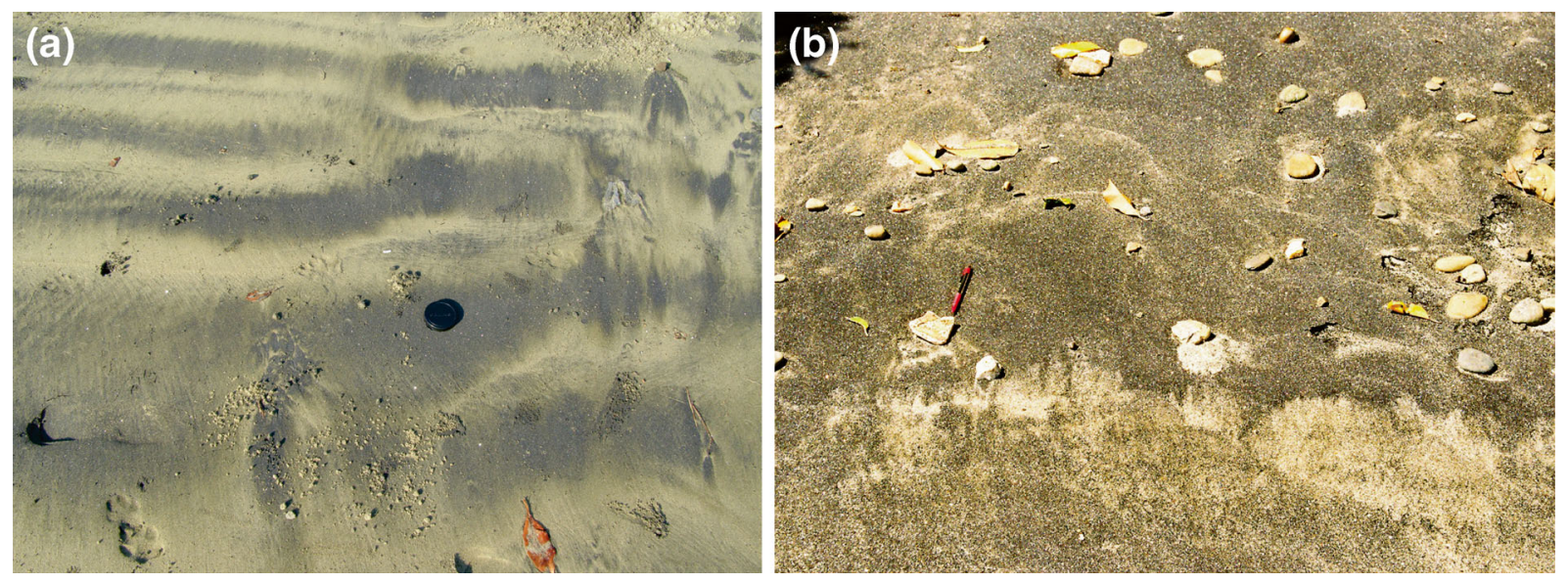

Figure 2. Field photographs showing (a) patchy occurrences of black sand along shoreline and (b) concentrated black sands rich in detrital spinels on the beach face.

groups (volcanic and peridotitic) was made possible once each individual grain was properly classified geochemically (see next). Therefore, this textural description is based solely on back scattered images (BSE), taken during performing the mineral analyses. Individual grains show evidences of transportation like abrasive rounding and edge microfracturing. The volcanic spinels are relatively fresh and the least altered. Further, because of their early crystallization from magma they commonly show an overall euhedral outline although the edges and corners are rounded a bit (figure 3ad). They are usually less pitted and at places show concentric compositional zoning indicative of magmatic crystallization (figure 3c). Some of these grains contain olivine as inclusions (figure $3 \mathrm{~d}$ ). On the contrary, mantle peridotitic spinels are extensively fractured and altered along grain margins (figure 3e-f). This may be linked to higher modal abundance of olivine (very prone to alteration) in peridotites. These peridotitic spinels are commonly more rounded in comparison to volcanic spinels. Nevertheless to mention here that residual, anhedral grains with amoeboid outline (eaten up margin), common to mantle peridotites are more susceptible to rounding in the course of transportation.

Since the placer spinels show variable degrees of oxidation and related alteration as evidenced from the development of ferrian chromite along grain margins and fractures, due care was taken in selecting the analytical points. Representative chemical analyses (28 nos.) out of a total of 81 spinel grains collected from four sample locations are presented in table 1 . The $\mathrm{Fe}^{2+}-\mathrm{Fe}^{3+}$ partitioning in spinels was calculated according to the charge balance equation of Droop (1978). The detrital spinels of Andaman Island show wide variation in the compositional parameters such as $\mathrm{Cr} \#[=\mathrm{Cr} /(\mathrm{Cr}+\mathrm{Al})], \mathrm{Mg} \#\left[=\mathrm{Mg} /\left(\mathrm{Mg}+\mathrm{Fe}^{2+}\right)\right]$,
$\mathrm{TiO}_{2}$ and $\mathrm{Al}_{2} \mathrm{O}_{3}$. The $\mathrm{TiO}_{2}$ and $\mathrm{Al}_{2} \mathrm{O}_{3}$ contents of the spinels vary between $0.00-1.39$ wt.\% and 5.0448.21 wt.\%, respectively. Likewise, $\mathrm{Cr} \#$ and $\mathrm{Mg} \#$ vary between $0.20-0.88$ and $0.26-0.77$, respectively. It is important to note that the Cr\# of spinel seldom exceeds 0.6 in peridotite and related rocks from the present day ocean floor, whereas, the same for island-arc peridotites ranges between 0.1 and 0.8 (Arai et al. 2006).

The wide compositional variation of the detrital spinels from Andaman Island signifies multiple sources of which residual mantle peridotites and volcanics are most relevant in ophiolitic settings (Lenaz et al. 2000). This is justified with the occurrence of a suite of variably depleted mantle peridotites and volcanics that commonly crop out in the Andaman Island. Thus, the discrimination between mantle and volcanic spinels is a requisite in constraining the spinel populations. The distinction between these two groups depends on the $\mathrm{TiO}_{2}$ content and the $\mathrm{Fe}^{2+} / \mathrm{Fe}^{3+}$ ratio (figure 4). Mantle spinels have statistically lower $\mathrm{TiO}_{2}\left(<0.2\right.$ wt. \%) and higher $\mathrm{Fe}^{2+} / \mathrm{Fe}^{3+}$ ratio $(>2)$ than volcanic spinels (Kamenetsky et al. 2001; Faupl et al. 2006), though some spinels in plutonic rocks from MOR and from hot spots are Tirich (Arai et al. 2011). By analogy with spinels from ophiolitic peridotites and mantle xenoliths worldwide, the low $\mathrm{TiO}_{2}$ and high $\mathrm{Fe}^{2+} / \mathrm{Fe}^{3+}$ end of the compositional spectrum belong to spinels derived from mantle peridotites (Lenaz et al. 2000). The peridotitic and volcanic spinels in the present study contribute nearly half of the total detrital spinel population of Andaman Island. Moreover, there is no contribution of peridotitic spinel from south-Andaman in the present population of detrital spinels, which is likely the reflection of volcanic dominated outcrops in this area.

The dependence of $\mathrm{Al}_{2} \mathrm{O}_{3}$ and $\mathrm{TiO}_{2}$ content in spinels is demonstrated to discriminate between 

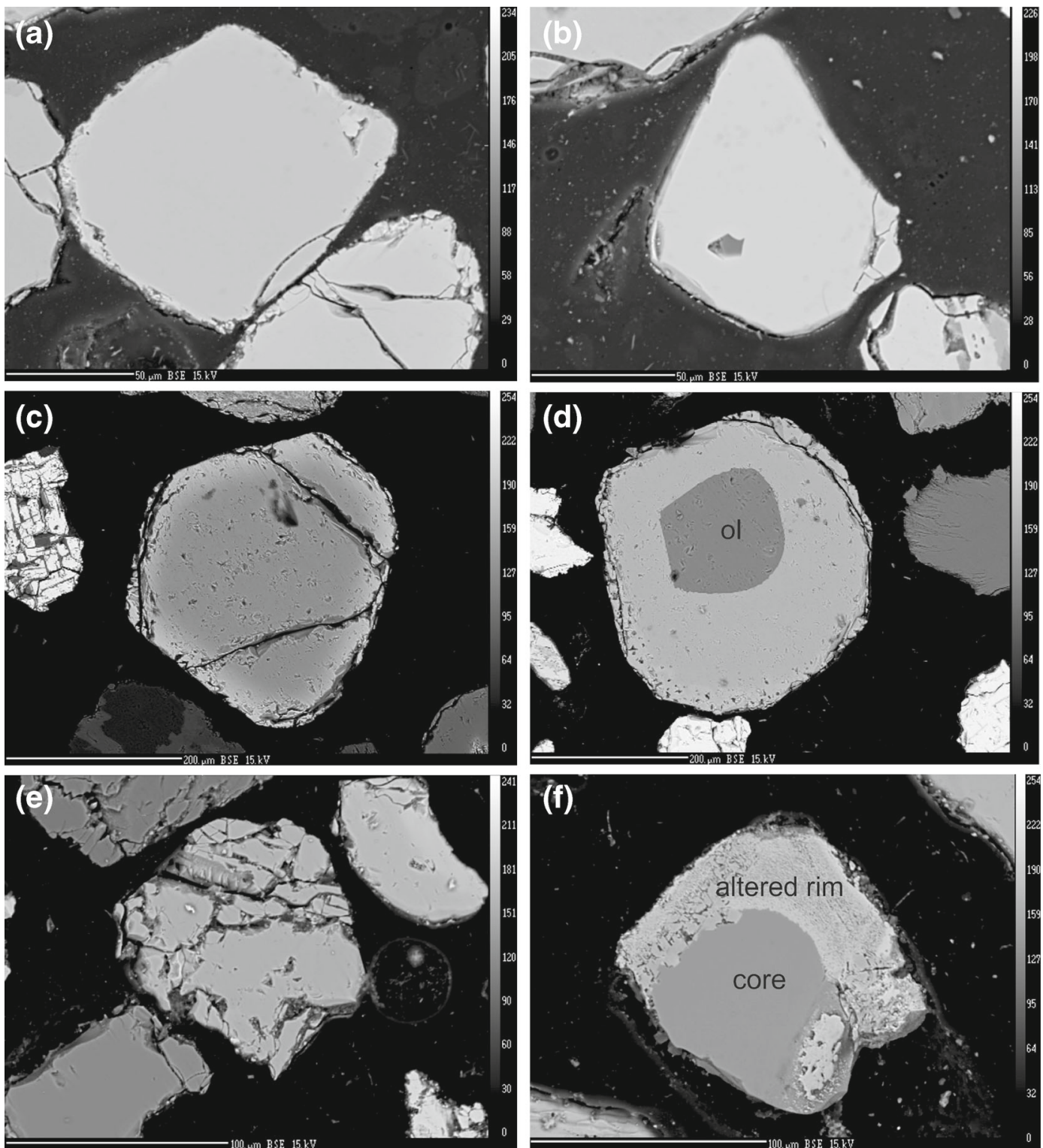

Figure 3. Backscattered electron images showing (a, b) fresh, edge-rounded, euhedral volcanic spinel with micro-fracturing at the edges; (c) polygonal volcanic spinel showing a weak compositional zoning; (d) detrital volcanic spinel with a silicate (olivine: ol) inclusion; (e) peridotitic spinel with extensive fracturing; and (f) heavily altered rim of a peridotitic spinel.

spinels crystallized from magmas in different geodynamic settings like MORB and island arcvolcanics (figure 5a). The representatives from south- and middle-Andaman have a wide range of $\mathrm{Al}_{2} \mathrm{O}_{3}$ and occupy both the island arc and MORB field whereas all north-Andaman samples plot in the MORB field. In general, arc-spinel $\mathrm{TiO}_{2}$ helps to distinguish between boninites/arc tholeiites and calc alkaline series, using a boundary nearly at $0.3-0.4$ wt.\% $\mathrm{TiO}_{2}$ (figure $5 \mathrm{~b}$ ). With reference to this compositional boundary, the arcspinels of south- and middle-Andaman belong to boninites/arc tholeiite series.

The peridotitic mantle spinels when plotted in the bivariate diagram of $\mathrm{Cr} \#$ vs. $\mathrm{Mg} \#$ (after Dick and Bullen 1984) occupy mostly the fore-arc peridotite field for middle-Andaman samples with few plots having higher $\mathrm{Cr} \#$ falling outside. In the case of north-Andaman samples, the entire spectrum from fore-arc peridotite to abyssal peridotite is represented (figure 6a). However, the spinel composition of outcrop mantle rocks from northAndaman occupies the abyssal peridotite field and that of middle-Andaman plots close to the forearc peridotite field, following the same trend as the detrital counterparts. More precisely, in a different type of the same bivariate diagram, the middleAndaman samples mostly belong to harzburgite source with few plots in the overlapping field with lherzolite whereas the north-Andaman samples occupy both the lherzolite and harzburgite field (figure 6b). The spinel composition of outcrop 


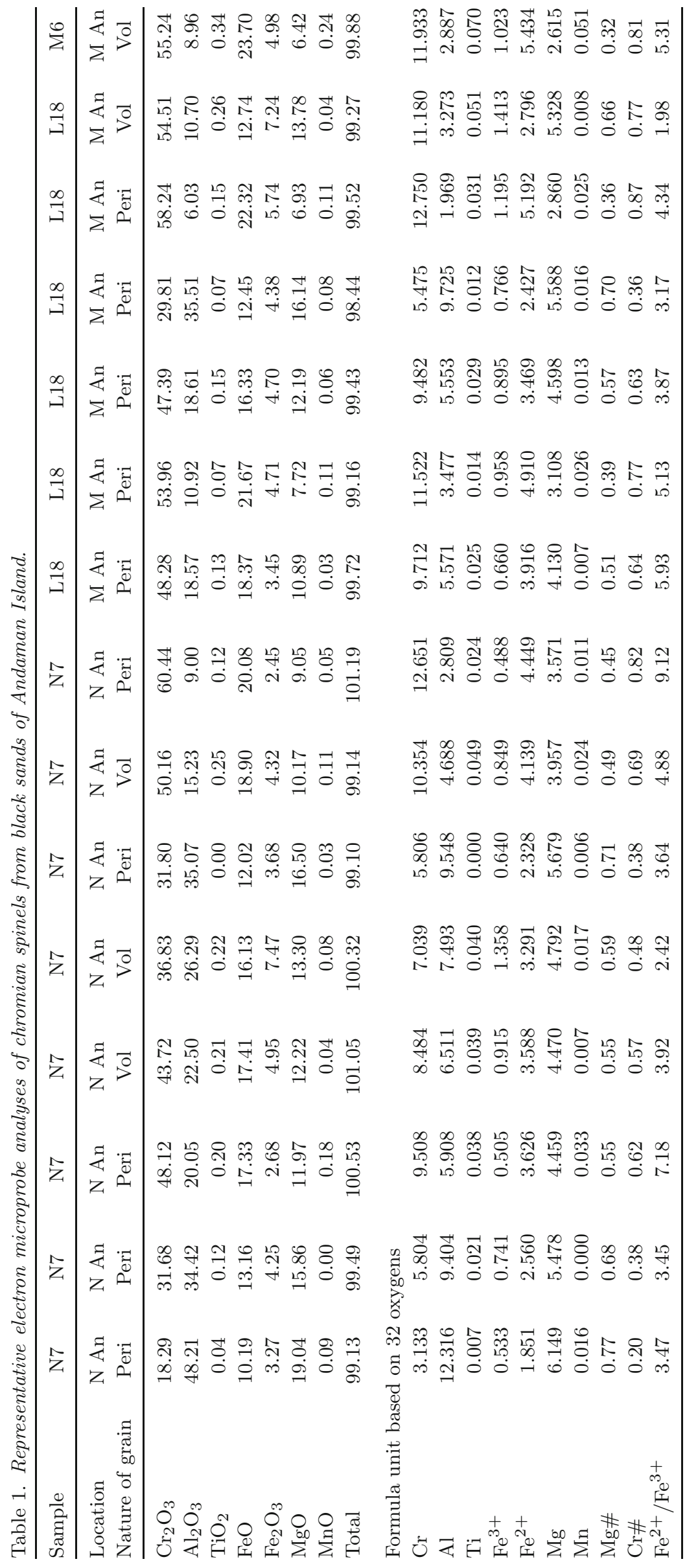




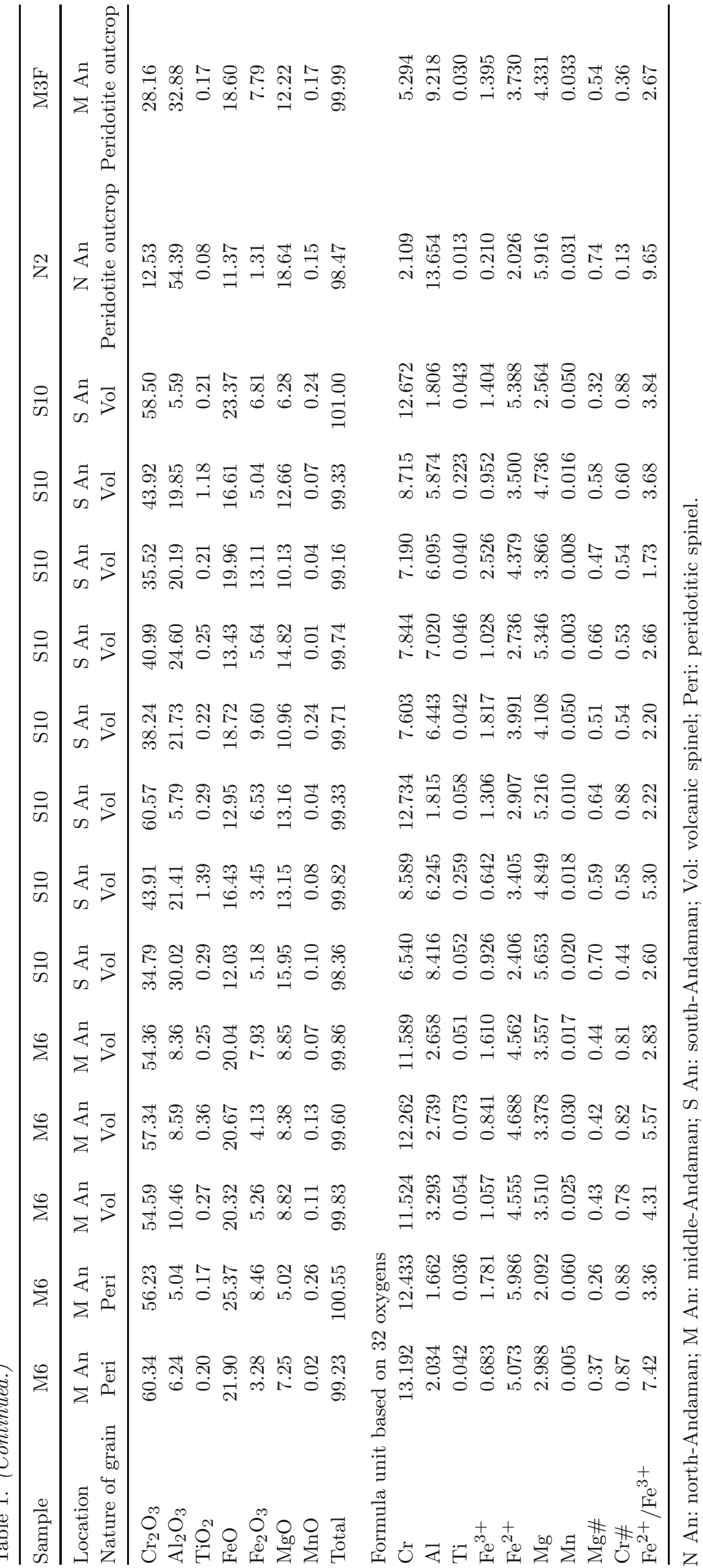


mantle rocks from north-Andaman falls close to the lherzolite field and that of middle-Andaman falls close to the trend defined by the detrital counterparts.

Mantle spinels of different tectonic settings have distinctive compositions based on $\mathrm{Al}_{2} \mathrm{O}_{3}$ wt. $\%$ vs. $\mathrm{TiO}_{2}$ wt.\% discrimination diagram (Kamenetsky et al. 2001) (figure 6c). The peridotitic mantle spinels of middle-Andaman (with mean $\mathrm{Al}_{2} \mathrm{O}_{3}$ of 18.16 wt.\% and standard deviation of 9.12)

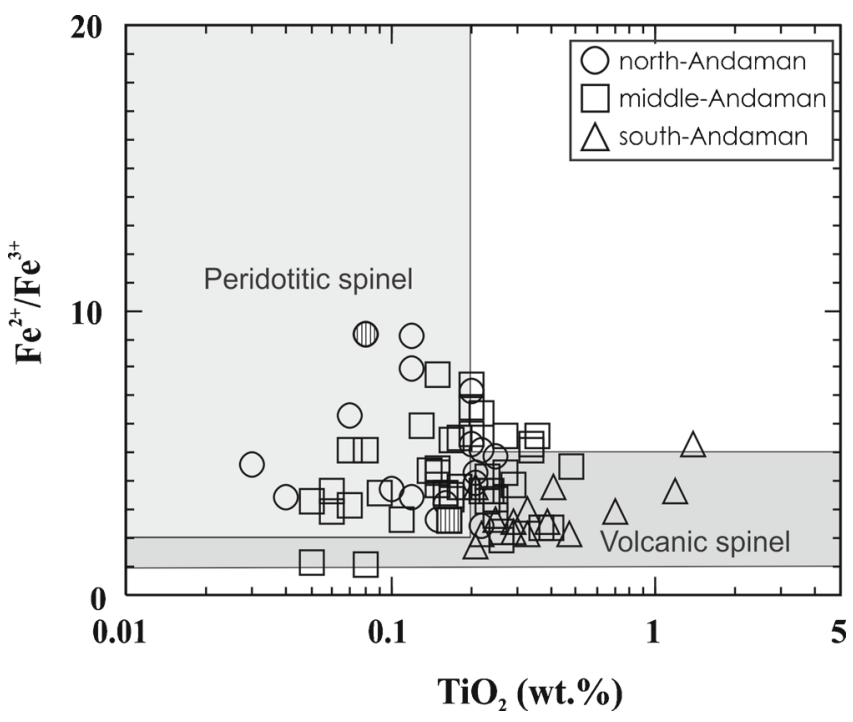

Figure 4. $\mathrm{TiO}_{2}$ vs. $\mathrm{Fe}^{2+} / \mathrm{Fe}^{3+}$ diagram showing the compositions of all detrital spinels studied. Fields define the compositions of peridotitic and volcanic spinel worldwide (Kamenetsky et al. 2001). Circle and square with bold outline and filled with vertical lines inside them represent spinel from outcrop of mantle rock from north- and middle-Andaman, respectively. mainly occupy the field of suprasubduction zone peridotites whereas those of north-Andaman samples (with mean $\mathrm{Al}_{2} \mathrm{O}_{3}$ of 31.27 wt. $\%$ and standard deviation of 13.95) occupy the entire field of MOR-type and suprasubduction zone peridotites.

\section{Discussion}

The total iron content of magmatic spinels is a function of the magma composition from which they crystallize, which in turn depends on the tectonic setting of the area concerned for that particular geologic time. However, ferrous-ferric ratio $\left(\mathrm{Fe}^{2+} / \mathrm{Fe}^{3+}\right)$ which is a reflection of the redox state of the magma is more akin to the depth level of crystallization. Taking into consideration the fact that $>95 \%$ of spinels from mantle rocks have $\mathrm{TiO}_{2}<0.2$ wt. $\%$ and volcanic spinels with $<0.2$ wt. $\%$ are uncommon and with $\mathrm{TiO}_{2}<0.1$ wt. $\%$ are exceptionally rare a compositional boundary between peridotitic and volcanic spinels has been arbitrarily set at $\mathrm{TiO}_{2}=0.2$ wt.\% (figure 4). Titanium $\left(\mathrm{Ti}^{4+}\right)$, present in magma, can enter into the spinel structure by couple substitution together with $\mathrm{Fe}^{2+}$, replacing two $\mathrm{Fe}^{3+}$ in the octahedral site (Ghosh and Konar 2011). Therefore, incorporation of titanium in the spinel lattice demands the spinel to be of partly inverse structure which is favoured if the spinel crystallizes under higher oxygen fugacity condition. The foregoing discussion explains why the volcanic spinels have characteristically higher $\mathrm{TiO}_{2}$ than the mantle spinels. The same when applied to detrital spinels in an ophiolitic setting, like in the present study, $\mathrm{TiO}_{2}-\mathrm{Fe}^{2+} / \mathrm{Fe}^{3+}$
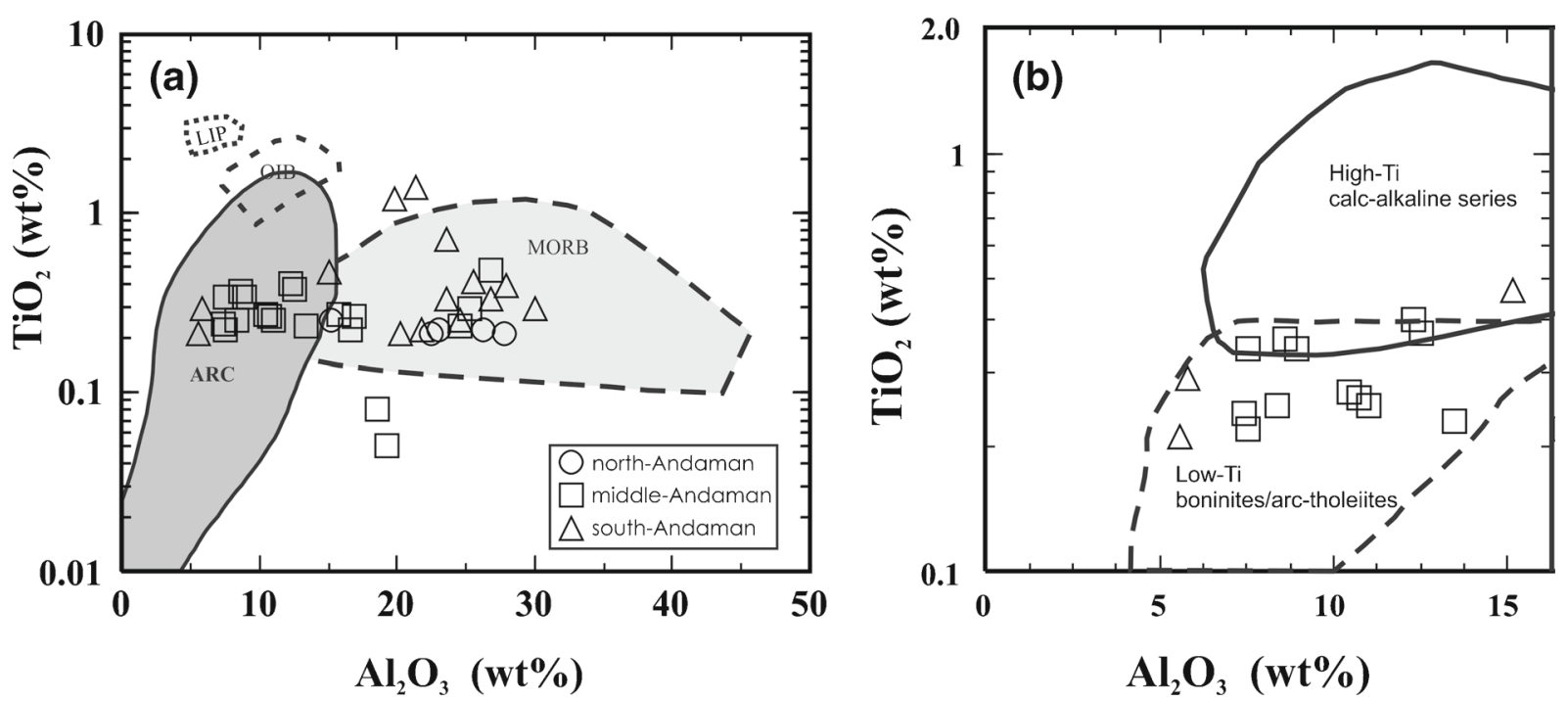

Figure 5. (a) $\mathrm{Al}_{2} \mathrm{O}_{3}$ vs. $\mathrm{TiO}_{2}$ compositional diagram of spinels discriminating between mid-ocean ridge basalt (MORB) and island-arc magmas (ARC) (Kamenetsky et al. 2001); (b) discrimination between arc spinels of low-Ti boninites/arc tholeiite and high-Ti calc-alkaline series in the bivariate $\mathrm{Al}_{2} \mathrm{O}_{3}$ vs. $\mathrm{TiO}_{2}$ diagram (Kamenetsky et al. 2001). Symbols are the same as in (a). 

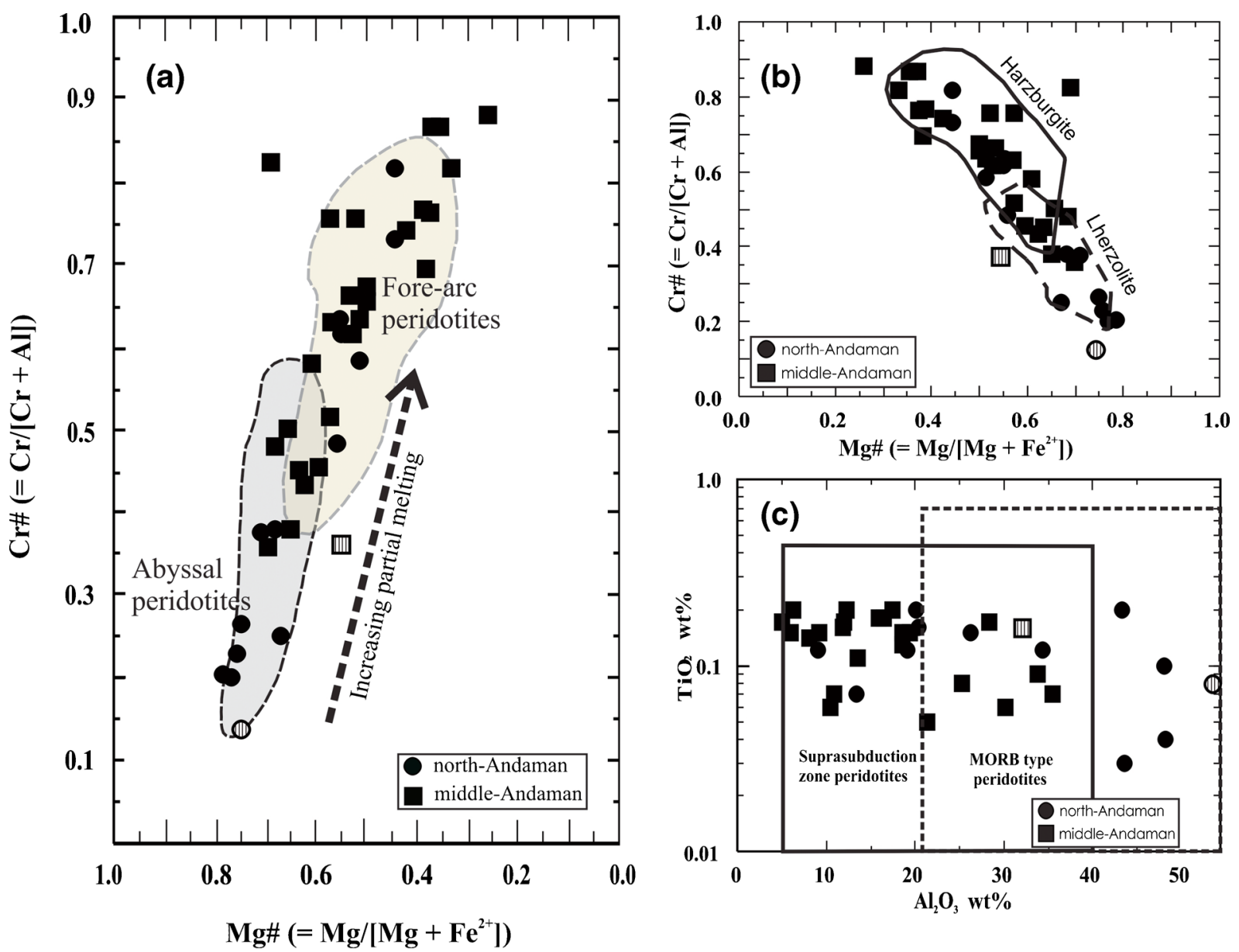

Figure 6. (a) Compositional variations of detrital peridotitic spinels of Andaman Island on bivariant Mg\# vs. Cr\# diagram. Fields for abyssal peridotites and fore-arc peridotites are taken from Ghosh et al. (2013); (b) bivariate Cr\# vs. Mg\# plot for detrital peridotitic spinels of the Andaman Island. The harzburgite and lherzolite fields are compiled from Pober and Faupl (1988) and Harada and Arai (1997); (c) $\mathrm{TiO}_{2}-\mathrm{Al}_{2} \mathrm{O}_{3}$ variations of detrital peridotitic spinels of Andaman Island with respect to modern day tectonic setting. Fields are from Kamenetsky et al. (2001). In all these figures circle and square with bold outline and filled with vertical lines inside them represent spinel from outcrop of mantle rock from north- and middle-Andaman, respectively.

systematically discriminates between peridotitic mantle source and the volcanic sources (figure 4).

$\mathrm{Al}_{2} \mathrm{O}_{3}$ abundances of volcanic spinels depend on the parent melt composition which together with other factors depends on the degree of partial melting (Kamenetsky et al. 2001). The lower content of the spinels in arc volcanics in comparison to MORB is due to the more depleted nature of the arc magma which is inherited by higher degree of mantle melting. On the other hand, the wide variation in $\mathrm{TiO}_{2}$ in arc-spinels probably reflects the fact that parental magmas are also variable in $\mathrm{TiO}_{2}$ as a result of mixing between primitive and evolved magmas and also between repetitive pulses (Kamenetsky et al. 2001). In case of Andaman ophiolite, the detrital volcanic spinels from northAndaman suggest a MORB parentage that might be related to spreading center tectonics, either a matured spreading centre like MOR or a nascent spreading centre like back-arc basin whereas, those from middle- and south-Andaman with their wide range of compositions indicate multiple parental magma, relevant to subduction setting.

The parent melts for spinel precipitation are commonly boninites or tholeiites with island arc characteristics (Malpas and Robinson 1987; Roberts 1988; Yumul and Balce 1994; Zhou et al. 1996). The degree of partial melting recorded in the peridotites from currently active volcanic arcs appears to decrease away from the fore-arc towards the back-arc region (Arai and Ishimaru 2008). The fore-arc region is characterized by harzburgites more depleted than that existing on abyssal floor. On the contrary, the peridotites in back-arc extensional regions are comparable to abyssal peridotites in terms of degree of depletion. As a consequence, the island arc region is characterized by high-Cr spinels, whereas the spreading centers are characterized by low-Cr varieties. The addition of water and other volatiles to the mantle wedge beneath the island arc enhances melting, leading to the production of highly depleted melts from which 
high-Cr spinels crystallise in contrast to the spreading centers where lower degrees of partial melting produce tholeiitic magmas from which lowCr, high-Al spinels crystallize (Zhou and Robinson 1994; Robinson et al. 1997).

Spinels in genetically related magmas and mantle restites have similar compositional ranges (Dick and Bullen 1984). Detrital volcanic spinels from north-Andaman have higher $\mathrm{Al}_{2} \mathrm{O}_{3}$ content whereas those with lowest values are from southAndaman (figure 5). This suggests that towards north, the melt parental to these spinels was less depleted, produced by lower degrees of partial melting. Alternatively, detrital peridotitic spinels of north-Andaman show a compositional spectrum between fore-arc peridotite and abyssal peridotite that may be linked to a switch over of the geodynamic setting, envisaged in many recent publications (Ghosh et al. 2013, 2014b; Ghosh and Bhatta 2014). Thus, the peridotite outcrops of northAndaman although lherzolite dominated, indicate the presence of harzburgite domain (not yet sampled) in the catchment areas as shown by this study.

\section{Conclusion}

Valuable information on the geochemical characteristics of the source rock can be obtained by studying the composition of detrital spinels. A systematic approach can distinguish the provenance protolith for a group of spinels having distinct geochemical characteristics in a heterogeneous population of black sands. This method can be equally applied for other ophiolitic terrains. Interpretations of the compositional variation in detrital spinels in such cases first require an assessment of the potential effect of mantle melting in spinel chemistry. The texture and mineral chemistry of the detrital spinels of Andaman Island indicate peridotites and volcanic rocks of the Andaman ophiolite as their source. The volcanic spinels show geochemical similarity to those derived from spreading centers (either MOR or back-arc) and arc-volcanics. On the other hand, the peridotitic spinels indicate partially depleted lherzolite and depleted harzburgite source of the ophiolite suite. It is inferred that a subduction related geodynamic setting with related arc magmatism was initiated long back in the late Mesozoic, much earlier than the Eocene accretion of the Andaman ophiolite, which is in conformity with the recent findings (Ghosh et al. 2012, 2013, 2014b).

\section{Acknowledgements}

The authors thank the anonymous reviewers for their comments and suggestions in improving the content. The authors acknowledge the financial support received from the Department of Science and Technology, India (SR/FTP/ES-65/2009) to carry out field work and microprobe analyses. S Sengupta and S Nandy of GSI, EPMA Laboratory, Kolkata are thankfully acknowledged for their assistance during the microprobe analyses.

\section{References}

Acharyya S K 2007 Collisional emplacement history of the Naga-Andaman ophiolites and the position of the eastern Indian suture; J. Asian Earth Sci. 29 229-242.

Allen R, Carter A, Najman Y, Bandopadhyaya P C, Chapman H J, Bickle M J, Garzanti E, Vezzoli G and Ando S 2007 New constraints on the sedimentation and uplift history of the Andaman-Nicobar accretionary prism, south Andaman Island; In: Formation and applications of the sedimentary record in arc collision zones (eds) Draut A, Clift P D and Scholl D W, Geol. Soc. Am. Spec. Paper 436 223-256.

Arai S 1992 Chemistry of chromium spinel in volcanic rocks as a potential guide to magma history; Min. Mag. 56 173-184.

Arai S and Okada H 1991 Petrology of serpentine sandstone as a key to tectonic development of serpentine belts; Tectonophys. 195 65-81.

Arai S and Ishimaru S 2008 Insights into petrological characteristics of the lithosphere of mantle wedge beneath arcs through peridotite xenoliths: A review; J. Petrol. 49 $665-695$.

Arai S, Kadoshima K and Morishita M 2006 Widespread arc-related melting in the mantle section of the northern Oman ophiolite as inferred from detrital chromian spinels; J. Geol. Soc. London 163 869-879.

Arai S, Okamura H, Kadoshima K, Tanaka C, Suzuki K and Ishimaru S 2011 Chemical characteristics of chromian spinel in plutonic rocks: Implications for deep magma processes and discrimination of tectonic setting; Island Arc 20 125-137.

Augé T 1987 Chromite deposits in the northern Oman ophiolite: Mineralogical constraints; Min. Dep. 22 1-10.

Bandopadhyay P C 2005 Discovery of abundant pyroclasts in Eocene Namunagarh Grit, south Andaman: Evidence for arc volcanism and subduction during the Palaeogene in the Andaman area; J. Asian Earth Sci. 25 97-107.

Bandopadhyay P C 2012 Re-interpretation of the age and environment of deposition of Paleogene turbidites in the Andaman and Nicobar Islands, western Sunda Arc; J. Asian Earth Sci. 45 126-137.

Barnes S J 1986 The distribution of chromium among orthopyroxene, spinel and silicate liquid at atmosphere pressure; Geochim. Cosmochim. Acta 50 1889-1909.

Barnes S J and Roeder P L 2001 The range of spinel compositions in terrestrial mafic and ultramafic rocks; J. Petrol. 42 2279-2302.

Bedard J H 1999 Petrogenesis of boninites from the Belt Cove Ophiolite, New Foundland, Canada: Identification of subducted source components; J. Petrol. 40 1853-1889.

Cookenboo H O, Bustin R M and Wilks K R 1997 Detrital chromian spinel compositions used to reconstruct the tectonic setting of provenance: Implications for orogeny in the Canadian cordillera; J. Sedim. Res. 67 116-123.

Curray J R 2005 Tectonics and history of the Andaman Sea Region; J. Asian Earth Sci. 25 187-232.

Dick H J B and Bullen T 1984 Chromian spinel as a petrogenetic indicator in abyssal and alpine-type peridotites 
and spatially associated lavas; Contrib. Mineral. Petrol. $8654-76$.

Droop G T R 1978 A general equation for estimating $\mathrm{Fe}^{3+}$ concentrations in ferromagnesian silicates and oxides from microprobe analysis, using stoichiometric criteria; Min. Mag. 51 431-435.

Evans B W and Frost B R 1975 Chrome-spinel in progressive metamorphism - a preliminary analysis; Geochim. Cosmochim. Acta 39 957-997.

Faupl P, Pavlopoulos A, Klotzli U and Petrakakis K 2006 On the provenance of mid-Cretaceous turbidites of the Pindos zone (Greece): Implications from heavy mineral distribution, detrital zircon ages and chrome spinel chemistry; Geol. Mag. 143 329-342.

Ghosh B and Konar R 2011 Chromites from metaanorthosites, Sittampundi layered igneous complex, Tamil Nadu, southern India; J. Asian Earth Sci. 42 1394-1402.

Ghosh B and Morishita T 2011 Andradite-uvarovite solid solutions from hydrothermally altered podiform chromitite, Rutland ophiolite, Andaman, India; Can. Min. 49 $573-580$.

Ghosh B and Bhatta K 2014 Podiform chromitites in lherzolitic mantle rocks (Andaman ophiolite, India): The role of magma/rock interaction and parental melt composition; Bull. Soc. Géol. Fran. 185 123-130.

Ghosh B, Pal T, Bhattacharya A and Das D 2009 Petrogenetic implications of ophiolitic chromite from Rutland Island, Andaman - a boninitic parentage in suprasubduction setting; Mineral. Petrol. 96 59-70.

Ghosh B, Morishita T and Bhatta K 2012 Detrital chromian spinels from beach placers of Andaman Islands, India: A perspective view of petrological characteristics and variations of the Andaman ophiolite; The Island Arc 21 $188-201$.

Ghosh B, Morishita T and Bhatta K 2013 Significance of chromian spinels from the mantle sequence of the Andaman Ophiolite, India: Paleogeodynamic implications; Lithos 164-167 86-96.

Ghosh B, Ray J and Morishita T 2014a Grain-scale plastic deformation of chromite from podiform chromitite of the Naga-Manipur ophiolite belt, India: Implication to mantle dynamics; Ore Geol. Rev. 56 199-208.

Ghosh B, Morishita T, Sen Gupta B, Tamura A, Arai S and Bandyopadhyay D 2014b Moho transition zone in the Cretaceous Andaman ophiolite, India: A passage from the mantle to the crust; Lithos 198-199 117-128.

Harada T and Arai S 1997 The application of detrital chromian spinel chemistry to geochemical survey of chromite deposit: Examples of the Kamuikotan tectonic belt, central Hokkaido, Japan; Res. Geol. 47 201-209.

Kadoshima K and Arai S 2001 Chemical analysis of detrital chromian spinels from the Lizard area, Cornwall: An attempt for lithological and petrological overview of the Lizard peridotite; Nue. Jahr. Min. Monatshefte 5 193209.

Kamenetsky V S, Crawford A J and Meffre S 2001 Factors controlling chemistry of magmatic spinel: An empirical study of associated olivine, Cr-spinel and melt inclusions from primitive rocks; J. Petrol. 42 655-671.

Karmalkar N R, Dessai A G, Duraiswami R A and Leblanc M 1995 Evidence of garnet to spinel peridotite transistion in the harzburgites of Indus ophiolite belt: An indication of their mantle origin; Curr. Sci. 69 767-770.

Karmalkar N R, Dessai A G and Duraiswami R A 1997 Morphological and chemical changes in spinels and their bearing on the cumulate or residual nature of the peridotites from the Indus Ophiolite, India; Indian Mineral. 31 12-23.

Lee Y 1999 Geotectonic significance of detrital chromian spinel: A review; Geosci. J. 3 23-29.

Lenaz D, Kamenetsky V S, Crawford A J and Princivalle F 2000 Melt inclusions in detrital spinel from the SE Alps (Italy-Slovenia): A new approach to provenance studies of sedimentary basins; Contrib. Mineral. Petrol. 139 $748-758$.

Luhr J F and Haldar D 2006 Barren Island Volcano (NE Indian Ocean): Island-arc high-alumina basalts produced by troctolite contamination; J. Vol. Geoth. Res. 149 $177-212$.

Malpas J and Robinson P T 1987 Chromite mineralization in the Troodos ophiolite, Cyprus; In: Evolution of chromium ore fields (ed.) Stowe C W (New York: Van NostrandReinhold Publishers), pp. 220-227.

Melcher F, Grum W, Simon G, Thalhammer T V and Stumpfl E F 1997 Petrogenesis of the ophiolitic giant chromite deposits of Kempisari, Kazakhstan; J. Petrol. 38 1419-1458.

Mitchell A H G 1985 Collision-related fore-arc and back-arc evolution of the northern Sunda arc; Tectonophys. 116 323-334.

Paul J, Burgmann R, Gaur V K, Bilham R, Larson K M, Ananda M B, Jade S, Mukal M, Anupama T S, Satyal G and Kumar D 2001 The motion and active deformation of India; Geophys. Res. Lett. 28 647-650.

Pober E and Faupl P 1988 The chemistry of detrital spinels and its implications for the geodynamic evolution of the Eastern Alps; Geologis. Runds. 77 641-670.

Press S 1986 Detrital spinels from alpinotype source rocks in Middle Devonian sediments of the Rhenish Massif; Geologis. Runds. 75 333-340.

Ray K K, Sengupta S and Van Den Hui H J 1988 Chemical characters of volcanic rocks of Andaman ophiolite, India; J. Geol. Soc. London 145 393-400.

Roberts S 1988 Ophiolitic chromitite formation: A marginal basin phenomenon?; Econ. Geol. 83 1034-1036.

Robinson P T, Zhou M F, Malpas J and Bai W J 1997 Podiform chromitites: Their composition, origin and environment of formation; Episodes 20 247-252.

Roy S K 1992 Accretionary prism in Andaman fore arc; Geol. Surv. India Spec. Publ. 29 273-280.

Sack R O and Ghiorso M S 1991 Chromian spinels as petrogenetic indicators: Thermodynamics and petrological applications; Am. Mineral. 76 827-847.

Vigny C et al. 2005 Insight into the 2004 Sumatra -Andaman earthquake from GPS measurements in southeast Asia; Nature 436 201-206.

Yumul G P and Balce G R Jr 1994 Supra-subduction zone ophiolite as favorable hosts for chromitite, platinum and massive sulfide deposits; J. South East Asian Earth Sci. 10 65-79.

Zhou M F and Robinson P T 1994 High-chromium and highaluminum podiform chromitites, western China: Relationship to partial melting and melt/rock interaction in the upper mantle; Intern. Geol. Rev. 36 678-686.

Zhou M F and Robinson P T 1997 Origin and tectonic environment of podiform chromite deposits; Econ. Geol. 92 259-262.

Zhou M F, Robinson P T, Malpas J and Li Z 1996 Podiform chromitites in the Lubusa ophiolite (southern Tibet): Implications for melt-rock interaction and chromite segregation in the upper mantle; J. Petrol. 37 3-21. 